\title{
Anthrovision
}

\section{Editorial Anthrovision issue 1.1}

\section{Beate Engelbrecht}

\section{OpenEdition}

\section{Journals}

Electronic version

URL: http://journals.openedition.org/anthrovision/605

DOI: 10.4000/anthrovision.605

ISSN: 2198-6754

\section{Publisher}

VANEASA - Visual Anthropology Network of European Association of Social Anthropologists

\section{Electronic reference}

Beate Engelbrecht, «Editorial Anthrovision issue 1.1 », Anthrovision [Online], 1.1 | 2013, Online since 01 August 2013, connection on 22 September 2020. URL : http://journals.openedition.org/anthrovision/ 605 ; DOI : https://doi.org/10.4000/anthrovision.605

This text was automatically generated on 22 September 2020

(c) Anthrovision 


\title{
Editorial Anthrovision issue 1.1
}

\author{
Beate Engelbrecht
}

Dear reader,

2 We welcome you to the first issue of the new online journal Anthrovision published by the Visual Anthropology Network of the European Association of Social Anthropologists (VANEASA). The title of our journal stands in certain ways for our programme and this first issue reflects some important points: Visual Anthropology is the focal point of the journal, but academic discussions are becoming more interdisciplinary and more complex, so the journal wants to publish quite diverse contributions using visual material in multiple ways. This issue discusses art, art practice, social media, media technology, indigenous media, participatory approaches, exhibition design, and film production. Being an online journal the articles integrate online material as images, photos, graphics, videos and interactive applications in one way of the other. We want to support this way of creative writing with visuals and are looking forward to receive corresponding contribution in future.

In this issues art is discussed in various ways. Dimitri Karadimas analyses the representations of angels and snakes in Renaissance images of Christ and the Virgin Maria thus offering a new interpretation in opposition to Leo Steinberg who examined these images exploring the sexuality in the representations. Quite different is Eduardo Navas study of remixes found on flickr and youtube relating it to postmodernity and globalisation thus giving an insight of how your society changes. N. Jade Gibson presents an artists' workshop in Cape Town in South Africa. Besides some methodological reflections on anthropological research and art work, she describes the different activities of the workshop thus installing art as a process which is integrating the community.

4 This leads us to the topic of participatory approaches using images and image making as point of departure. N. Jade Gibson describes workshop space, a local church bazaar, the creativity of the residents in the neighbourhood, the conversion of a street house into a gallery, performances in the public, the exhibition and the festival day at the end of the workshop thus giving an insight of how the workshop was an opportunity for many people to engage. Jessica de Largy Healy presents the indigenous media work of 
the Yolngu people living in North-eastern Arnhem Land in Australia. Having participated since the 60ies in ethnographic film projects and having been fight for their rights since a long time the Yolngu developed a special interest in using media for their purposes. New technology as the Internet allows them to present their culture to a worldwide public and to communicate between themselves constantly. Especially the Internet offers the possibility to respond to information by commenting the reports textually but also visually thus participating directly in an exchange on Yolngu culture.

Eduardo Navas and Jessica de Largy Healy discuss both the Internet, the facilities of uploading clips on youtube, the use social media and therefore the possibility to create a new productions and remixes. Whereas de Largy Healy mainly stresses the positive effects of the online presentations of Yolngu culture, Eduardo Navas discusses the difficulty one encounters using the Internet for search and communication. He analysis the way the big search engines are working and how the search results do not allow to get an historical overview of productions. Taking remixes as an example he critically examines the politics of the search engines and social spaces as flickr and youtube, the fragmentation of information and the unreliability concerning the archiving of the material. Moreover, technological changes generate new problems as not being able to play older productions anymore.

6 Exhibition presents another topic being addressed in the papers. N. Jade Gibson describes very well how the workshop results were exhibited in various locations in the community, in private homes and public spaces. Susanne B. Schmitt did research in a German Science Museum analysing how they work and participating in the installation of an exhibition. Taking the "Dia de los Muertos" in Mexico as a point of departure they discussed how besides the visible objects - the colourful altars with flours, memorabilia and food - the sensory context of the ceremonies could be exposed. A Mexican community in Berlin celebrating the "Dia de los Muertos" allowed them to film the public ceremonies and use the recordings in the exhibition.

7 Films, videos, clips as well as photos played in various contributions an important but not a central role. The diversity of the usage of images - as documentation, communication media, object of art etc. - demonstrates how large the field of the study and the usage of these media is.

Very often Visual Anthropology is reduced to "Ethnographic Film Making". We would like to emphasise that we aim for contribution from all areas of Visual Anthropology and Visual Studies as well as from Anthropology of Art, Media Anthropology, and Digital Anthropology ... We would like to animate contributors to use the multiple facilities of online publication integrating digital resource which might be stored at the journal digital archive or archived or found on the Internet.

June 2013 
AUTHOR

BEATE ENGELBRECHT

Director of Anthrovision 